\title{
PENGEMBANGAN DAN VALIDASI METODA ANALISIS \\ PENENTUAN KADAR TABLET DIETILKARBAMAZINE SITRAT 100 MG \\ DENGAN METODA KROMATOGRAFI CAIR KINERJA TINGGI
}

\author{
Kusdi Hartono, Ginayanti Hadisoebroto, Muhammad Hasbullah \\ Prodi Farmasi, Universitas Al-Ghifari
}

\begin{abstract}
ABSTRAK
Penetapan kadar obat dalam suatu sediaan membutuhkan suatu metoda yang teliti dan akurat serta waktu yang lebih singkat. Telah dilakukan pengembangan metoda analisis penentuan kadar tablet Dietilkarbamazin Sitrat $100 \mathrm{mg}$ dengan metoda kromatografi cair kinerja tinggi dengan mengoptimasi perbandingan komposisi fase gerak campuran larutan dapar fosfat dan metanol dengan perbandingan $(60: 40)$, (70:30), dan $(80: 20)$. Hasil optimasi fase gerak menunjukan perbandingan komposisi fase gerak campuran larutan dapar fosfat dan metanol (80:20) yang paling optimal, Selanjutnya dilakukan validasi metoda analisisnya. Hasil validasi pada penelitian ini menujukkan hasil yang memenuhi persyaratan validasi yaitu relatif standar deviasi (RSD ) pada uji presisi 0,4231\% (syarat $\leq 2,0 \%$ ), rata-rata \% recovery akurasi 99,48\% (syarat 98,0\% $102,0 \%$ ), Nilai r pada uji Linearitas 0,9994 (syarat r 0,999), RSD Kesesuaian sistem 0,2283 \%, dan Selektivitas 100,30\%-100,49\% (syarat 95,0\%-105,0\%).
\end{abstract}

Kata kunci : Dietilkarbamazin Sitrat, KCKT, Validasi, Dapar Fosfat, Metanol.

\section{ABSTRACT}

Determination of drug levels in a preparation requires a meticulous and accurate method as well as a shorter time. The research about development of analytical methods determination of tablet Diethylcarbamazine Citrate $100 \mathrm{mg}$ with the method of high performance liquid chromatography by optimizing the ratio of mobile phase composition mix solution of phosphate buffer and methanol in the ratio (60: 40), (70: 30), and (80:20), The results show the optimization of mobile phase composition ratio of mobile phase mixture of phosphate buffer solution and methanol (80: 20) The most optimal, then validated method of analysis. The tests in this study showed results that meet the requirements of validation that the relative standard deviation (RSD) on precision test $0,4231 \%$ (requirement $\leq 2,0 \%)$, the average \% recovery accuracy of $99,48 \%(98,0 \%-102,0 \%$ ), $r$ Value Reviewed 0,9994 Linearity test (requirement $r$ 0,999), RSD systems Conformity $0,2283 \%$, and the selectivity of 100,30\% - 100,49\% (requirement 95,0\% - 105,0\%).

Keywords: Diethylcarbamazine Citrate, HPLC, Validation, Phosphate Buffer, Methanol.

\section{Pendahuluan}

Dietilkarbamazin merupakan obat pilihan pertama untuk filariasis. Obat ini dipasarkan sebagai garam sitrat, berbentuk kristal, tidak berwarna rasa tidak enak dan mudah larut dalam air. Untuk melakukan penetapan kadar obat dalam suatu sediaan dibutuhkan suatu metoda yang teliti dan akurat. penetapan kadar tablet dietilkarbamazin dilakukan dengan menggunakan metoda Kromatografi Cair Kinerja Tinggi ( USP 36 NF 31, 2013). 
Kromatografi Cair Kinerja Tinggi (KCKT) adalah merupakan teknik pemisahan berdasarkan fase diam berupa padatan dan fase gerak berupa cairan. Pemisahan dicapai melalui partisi, absorpsi atau proses pertukaran ion. Fase diam yang umum digunakan adalah silika yang dimodifikasi atau butiran polimerik. Fase gerak merupakan pelarut atau campuran pelarut seperti tertera dalam masing-masing monografi (FI Edisi V, 2014 ). Secara umum komponen utama dari KCKT adalah wadah eluen/ fase gerak, pompa, injektor, kolom, detektor, dan integrator.

Sebelumnya telah dilakukan optimasi metoda penetapan kadar tablet Dietilkarbamazin Sitrat $100 \mathrm{mg}$, termasuk juga validasi metode analisisnya menggunakan metode KCKT. Hasil pemisahannya menunjukkan kromatogram yang baik serta hasil uji validasi metoda analisisnya memenuhi syarat, akan tetapi waktu retensi masih terlalu panjang $\pm 17-$ 20 menit sehingga waktu analisanya menjadi lama. Dimana fase gerak yang digunakan adalah campuran larutan dapar fosfat dan metanol dengan perbandingan 90: 10, sedangkan hasil validasi metoda analisanya adalah relatif standar deviasi (RSD ) pada uji presisi 0,0998\%, \% recovery akurasi 100,32 $\%$, nilai r pada uji Linearitas 0,9992 dan selektivitas $101,11 \%-101,29 \%$.

Pada penelitian ini akan dilakukan pengembangan metoda analisis dengan mengoptimasi perbandingan komposisi fase gerak , campuran larutan dapar fosfat dan metanol, yaitu dengan perbandingan (60:40 ), (70:30), dan $(80: 20)$. Setelah didapat komposisi fase gerak yang optimal, selanjutnya akan dilakukan validasi metoda analisis tersebut sehingga diharapkan nantinya waktu analisa tidak terlalu lama.

\section{Tujuan}

Penelitian ini dilakukan dengan tujuan untuk mempercepat waktu analisis penetapan kadar tablet Dietilkarbamazin Sitrat 100 mg, tapi tetap memberikan hasil kromatogram yang baik dan memenuhi standar validasi.

\section{Bahan dan Alat}

\subsection{Alat}

HPLC shimadzu LC 2030, Labu ukur 50 ml, Timbangan analitik mettler toledo, Pipet volume $5 \mathrm{ml}$, Gelas kimia $1000 \mathrm{ml}$, Botol reagen $1000 \mathrm{ml}$, Batang pengaduk .

\subsection{Bahan}

Tablet Dietilkarbamazin Sitrat $100 \mathrm{mg}$, Kalium Dihidrogen Fosfat, Metanol Aquabidest

\section{Metodologi}

4.1 Pemilihan komposisi fase gerak

1. Siapkan larutan standar $100 \%$, larutan blanko dan larutan sampel .

a. Pembuatan larutan standar $100 \%$.

Timbang baku pembanding Dietilkarbamazin Sitrat sebanyak \pm 50 mg, masukkan ke dalam labu ukur 50 $\mathrm{mL}$, tambahkan $20 \mathrm{~mL}$ pelarut, sonikasi selama \pm 10 menit, kemudian tanda bataskan dengan pelarut hingga $50 \mathrm{~mL}$, homogenkan . Pipet $5 \mathrm{~mL}$ kemudian encerkan dengan pelarut hingga $50 \mathrm{~mL}$. Kemudian saring dengan membran filter $0,45 \mu \mathrm{m}$.

b. Pembuatan larutan blanko Larutan blanko berasal dari pelarut yang digunakan yaitu dapar fosfat .

c. Pembuatan larutan sampel

Timbang seksama Sampel tablet Dietilkarbamazin Sitrat $100 \mathrm{mg}$ sebanyak $\pm 150 \mathrm{mg}$, masukkan ke dalam labu ukur $50 \mathrm{~mL}$, tambahkan $20 \mathrm{~mL}$ pelarut, sonikasi selama \pm 10 menit , kemudian tanda bataskan dengan pelarut hingga $50 \mathrm{~mL}$, homogenkan. saring melalui kertas saring. Pipet $5 \mathrm{~mL}$ filtrat tersebut kemudian encerkan dengan pelarut hingga $50 \mathrm{~mL}$. Kemudian saring dengan membran filter $0.45 \mu \mathrm{m}$. Sampel yang ditimbang : $\mathrm{A}=\ldots \mathrm{mg}$ $\mathrm{B}=\ldots \mathrm{mg}$.

2. Ukur luas area larutan standar, larutan blanko dan larutan sampel dengan menggunakan HPLC pada panjang gelombang $220 \mathrm{~nm}$. Hitung kadar zat aktifnya .

\subsection{Validasi Metoda Analisis}

\section{Presisi (Repeatabilitas)}

a. Pembuatan larutan induk (S1)

Timbang seksama sampel tablet Dietilkarbamazin Sitrat $100 \mathrm{mg}$ sebanyak $\pm 150 \mathrm{mg}$, masukkan ke dalam labu ukur $50 \mathrm{~mL}$, tambahkan 20 $\mathrm{mL}$ pelarut, sonikasi selama \pm 10 menit kemudian tanda bataskan dengan pelarut hingga $50 \mathrm{~mL}$, homogenkan. saring melalui kertas saring . 
b. Pembuatan larutan sampel $100 \%$

(S2).

Pipet $5 \mathrm{~mL}$ filtrat tersebut kemudian encerkan dengan pelarut hingga 50 $\mathrm{mL}$. Kemudian saring dengan membran filter $0,45 \mu \mathrm{m}$. Bobot ratarata 10 tablet $=\ldots$ mg. Periksa larutan sampel dengan konsentrasi $100 \%$ sebanyak 10 kali berturut-turut.

\section{Akurasi}

Buat larutan sampel dengan konsentrasi $80 \%$ , $100 \%$, dan $120 \%$ dari larutan induk (S1) sesuai dengan tabel berikut :

\begin{tabular}{|c|c|c|c|}
\hline $\begin{array}{c}\text { Konsentrasi } \\
(\%)\end{array}$ & $\begin{array}{c}\text { Larutan } \\
\text { Induk } \\
(\mathrm{mL})\end{array}$ & $\begin{array}{c}\text { Konsentrasi } \\
\text { Dietilkarbamazin Sitrat } \\
(\mu \mathrm{g} / \mathrm{mL})\end{array}$ & $\begin{array}{c}\text { Volume } \\
\text { Akhir } \\
(\mathrm{mL})\end{array}$ \\
\hline 80 & 4 & 80 & 50 \\
\hline 100 & 5 & 100 & 50 \\
\hline 120 & 6 & 120 & 50 \\
\hline
\end{tabular}

Periksa larutan sampel dengan konsentrasi $80 \%, 100 \%$, dan $120 \%$ masing-masing sebanyak 3 kali berturut - turut.

\section{Linearitas}

Buat seri larutan sampel dengan konsentrasi $70 \%, 80 \%, 90 \%, 100 \%, 110$
$\%, 120 \%$, dan $130 \%$ yang dilakukan sesuai dengan tabel berikut :

\begin{tabular}{|c|c|c|c|}
\hline Konsentrasi $(\%)$ & $\begin{array}{c}\text { Larutan Induk } \\
(\mathrm{mL})\end{array}$ & $\begin{array}{c}\text { Konsentrasi } \\
\text { Dietilkarbamazin Sitrat } \\
(\mu \mathrm{g} / \mathrm{mL})\end{array}$ & $\begin{array}{c}\text { Volume Akhir } \\
(\mathrm{mL})\end{array}$ \\
\hline 70 & 3,5 & 70 & 50 \\
\hline 80 & 4 & 80 & 50 \\
\hline 90 & 4,5 & 90 & 50 \\
\hline 100 & 5 & 100 & 50 \\
\hline 110 & 5,5 & 110 & 50 \\
\hline 120 & 6,0 & 120 & 50 \\
\hline 130 & 6,5 & 130 & 50 \\
\hline
\end{tabular}

Ukur 7 seri larutan dari konsentrasi di atas dengan HPLC pada panjang gelombang $220 \mathrm{~nm}$. Kemudian buat garis linearitasnya, hitung slope dan regresi linearitasnya .

\section{Selektivitas}

Siapkan larutan standar $100 \%$, larutan blanko dan larutan sampel.

a. Pembuatan larutan standar $100 \%$

Timbang baku pembanding

Dietilkarbamazin Sitrat sebanyak \pm 50

$\mathrm{mg}$, masukkan ke dalam labu ukur $50 \mathrm{~mL}$, tambahkan $20 \mathrm{~mL}$ pelarut, sonikasi selama \pm 10 menit, kemudian tanda bataskan dengan pelarut hingga $50 \mathrm{~mL}$, homogenkan. Pipet $5 \mathrm{~mL}$ kemudian encerkan dengan pelarut hingga $50 \mathrm{~mL}$. Kemudian saring dengan membran filter $0,45 \mu \mathrm{m}$.

b. Pembuatan larutan blanko Larutan blanko berasal dari pelarut yang digunakan yaitu dapar fosfat.

c. Pembuatan larutan sampel
Timbang seksama sampel tablet Dietilkarbamazin Sitrat $100 \mathrm{mg}$ sebanyak $\pm 150 \mathrm{mg}$, masukkan ke dalam labu ukur $50 \mathrm{~mL}$, tambahkan $20 \mathrm{~mL}$ pelarut, sonikasi selama 10 menit, kemudian tanda bataskan dengan pelarut hingga $50 \mathrm{~mL}$, homogenkan, saring melalui kertas saring. Pipet $5 \mathrm{~mL}$ filtrat tersebut kemudian encerkan dengan pelarut hingga $50 \mathrm{~mL}$. Kemudian saring dengan membran filter $0.45 \mu \mathrm{m}$. Sampel yang ditimbang : $\mathrm{A}=\ldots$ $\mathrm{mg} \quad \mathrm{B}=\ldots \mathrm{mg} \quad \mathrm{C}=\ldots \mathrm{mg}$.

Ukur luas area larutan standar, larutan blanko dan larutan sampel dengan menggunakan HPLC pada panjang gelombang $220 \mathrm{~nm}$. Hitung kadar zat aktifnya.

\section{Stabilitas Larutan}


Ulangi pemeriksaan larutan sampel yang telah disimpan selama 24 jam dan seterusnya

\section{Rentang}

Hasil analisis pada penentuan akurasi dan linearitas, didapatkan hasil sebagai berikut :

Akurasi

Rentang antara : $80 \%-120 \%$

Hasil Pemeriksaan : .......(syarat 98,0 \% $-102,0 \%$ )

\section{Linearitas}

Rentang antara : $70 \%-130 \%$

Hasil Pemeriksaan : ......( syarat : $r \geq$ 0,999 )

Kesimpulan

\section{Kesesuaian Sistem}

Injekkan larutan standar sebanyak 5 kali, lalu hitung uji kesesuaian sistem dari 5 kromatogram standar.

Kriteria penerimaan : RSD $\leq 2.0 \%$

Kesimpulan

\section{Robustness}

Siapkan larutan standar $100 \%$.

Timbang baku pembanding

Dietilkarbamazin Sitrat sebanyak $\pm 50 \mathrm{mg}$, masukkan ke dalam labu ukur $50 \mathrm{~mL}$, tambahkan $20 \mathrm{~mL}$ pelarut, sonikasi selama \pm

\section{Hasil dan Pembahasan}

\subsection{Pemilihan komposisi fase gerak}

Standar yang ditimbang : $50,2 \mathrm{mg}$

Sampel yang ditimbang : $\mathrm{A}=150,1 \mathrm{mg}$ $\mathrm{B}=150,1 \mathrm{mg}$ bila diperlukan. Standar yang ditimbang yaitu Dietilkarbamazin Sitrat : $\pm 50 \mathrm{mg}$.

10 menit, kemudian tanda bataskan dengan pelarut hingga $50 \mathrm{~mL}$, homogenkan. Pipet 5 $\mathrm{mL}$ kemudian encerkan dengan pelarut hingga $50 \mathrm{~mL}$. Kemudian saring dengan membran filter $0,45 \mu \mathrm{m}$.

\section{Pembuatan larutan blanko}

Larutan blanko berasal dari pelarut yang digunakan yaitu dapar fosfat.

\section{Pembuatan larutan sampel}

Timbang seksama sampel tablet Dietilkarbamazin Sitrat $100 \mathrm{mg}$ sebanyak \pm $150 \mathrm{mg}$, masukkan ke dalam labu ukur 50 $\mathrm{mL}$, tambahkan $20 \mathrm{~mL}$ pelarut, sonikasi selama \pm 10 menit, kemudian tanda bataskan dengan pelarut hingga $50 \mathrm{~mL}$, homogenkan, saring melalui kertas saring. Pipet $5 \mathrm{~mL}$ filtrat tersebut kemudian encerkan dengan pelarut hingga $50 \mathrm{~mL}$. Kemudian saring dengan membran filter $0,45 \mu \mathrm{m}$. Sampel yang ditimbang: $\mathrm{A}=\ldots . \mathrm{mg} \quad \mathrm{B}=\ldots . \mathrm{mg} \mathrm{C}=\ldots . \mathrm{mg}$.

Larutan standar, larutan blanko dan larutan sampel diukur menggunakan HPLC pada panjang gelombang $220 \mathrm{~nm}$ menggunakan kolom yang berbeda dari yang digunakan dalam pemeriksaan sebelumnya yaitu kolom ..., sebelumnya menggunakan kolom ..... Hitung kadar zat aktifnya.

Bobot rata-rata 10 tablet $=302,34 \mathrm{mg}$

a. Fase gerak campuran larutan dapar fosfat dan metanol dengan perbandingan (60 : 40)

Verifikasi

\begin{tabular}{|c|c|}
\hline Standar & Luas Area \\
\hline 1 & 2197138 \\
\hline 2 & 2198981 \\
\hline 3 & 2194584 \\
\hline 4 & 2188826 \\
\hline 5 & 2168268 \\
\hline Rata-rata & 2189560 \\
\hline RSD & 0,5710 \\
\hline
\end{tabular}

\begin{tabular}{|c|c|c|c|c|}
\hline Larutan Uji & Luas Area & $\begin{array}{c}\text { Konsentrasi } \\
\text { Dietilkarbamazin Sitrat } \\
(\mu \mathrm{g} / \mathrm{mL})\end{array}$ & $\begin{array}{c}\text { Kadar } \\
(\%)\end{array}$ & $\mathrm{pH}$ \\
\hline Larutan Standar & 2189560 & 100,40 & 99,73 & 4,40 \\
\hline Larutan Blanko & - & - & - & 4,35 \\
\hline Larutan Sampel A & 2137918 & 99,29 & 98,46 & 4,60 \\
\hline Larutan Sampel B & 2136846 & 99,29 & 98,42 & 4,60 \\
\hline
\end{tabular}


Lihat lampiran 1. Kromatogram Perbadingan Fase Gerak 60 : 40

b. Fase gerak campuran larutan dapar fosfat dan metanol dengan perbandingan $(70: 30)$

\begin{tabular}{|c|c|}
\multicolumn{2}{|c|}{ Verifikasi } \\
\hline Standar & Luas Area \\
\hline 1 & 2247038 \\
\hline 2 & 22313397 \\
\hline 3 & 2246052 \\
\hline 4 & 2220208 \\
\hline 5 & 2224807 \\
\hline Rata-rata & 2233900 \\
\hline RSD & 0,5467 \\
\hline
\end{tabular}

\begin{tabular}{|c|c|c|c|c|}
\hline Larutan Uji & Luas Area & $\begin{array}{c}\text { Konsentrasi } \\
\text { Dietilkarbamazin Sitrat } \\
(\mu \mathrm{g} / \mathrm{mL})\end{array}$ & $\begin{array}{c}\text { Kadar } \\
(\%)\end{array}$ & $\mathrm{pH}$ \\
\hline Larutan Standar & 2233900 & 100,40 & 99,73 & 4,40 \\
\hline Larutan Blanko & - & - & - & 4,35 \\
\hline Larutan Sampel A & 2210967 & 99,29 & 99,81 & 4,60 \\
\hline Larutan Sampel B & 2211339 & 99,29 & 99,82 & 4,60 \\
\hline
\end{tabular}

Lihat lampiran 2. Kromatogram Perbandingan Fase Gerak $70: 30$

c. Fase gerak campuran larutan dapar fosfat dan metanol dengan perbandingan $(80: 20)$

Verifikasi

\begin{tabular}{|c|c|}
\hline Standar & Luas Area \\
\hline 1 & 2303228 \\
\hline 2 & 2306720 \\
\hline 3 & 2315951 \\
\hline 4 & 2311093 \\
\hline 5 & 2314287 \\
\hline Rata-rata & 2310256 \\
\hline RSD & 0,2283 \\
\hline
\end{tabular}

\begin{tabular}{|c|c|c|c|c|}
\hline Larutan Uji & Luas Area & $\begin{array}{c}\text { Konsentrasi } \\
\text { Dietilkarbamazin Sitrat } \\
(\mu \mathrm{g} / \mathrm{mL})\end{array}$ & $\begin{array}{c}\text { Kadar } \\
(\%)\end{array}$ & $\mathrm{pH}$ \\
\hline Larutan Standar & 2310256 & 100,40 & 99,73 & 4,40 \\
\hline Larutan Blanko & - & - & - & 4,35 \\
\hline Larutan Sampel A & 2293898 & 99,29 & 100,13 & 4,60 \\
\hline Larutan Sampel B & 2297750 & 99,29 & 100,30 & 4,60 \\
\hline
\end{tabular}

Lihat lampiran 3. Kromatogram Perbandingan Fase Gerak $80: 20$

Setelah dilakukan optimasi terhadap komposisi fase gerak pada penentuan kadar tablet Dietilkarbamazin Sitrat $100 \mathrm{mg}$, maka didapat komposisi fase gerak yang optimal yaitu campuran larutan dapar fosfat dan metanol dengan perbandingan (80:20) karena pada komposisi ini didapat waktu retensi lebih cepat dan pemisahan antara kromatogram sampel dengan pengotor dari kolom lebih baik jika dibandingkan dengan komposisi fase gerak $(60: 40)$ dan $(70: 30)$.

5.2 Validasi Metoda Analisis

5.2.1 Presisi (Repeatabilitas)

a. Prosedur Pelaksanaan 
Standar yang ditimbang $=50,2 \mathrm{mg}$

Sampel yang ditimbang $=150,1 \mathrm{mg}$

Bobot rata-rata 10 tablet $=302,34 \mathrm{mg}$

b. Hasil Pemeriksaan
Larutan sampel $100 \quad \% \quad$ (S2) diukur menggunakan HPLC pada panjang gelombang $220 \mathrm{~nm}$ sebanyak $10 \mathrm{kali}$ berturut-turut.

Hasil yang diperoleh adalah sebagai berikut :

\begin{tabular}{|c|c|c|}
\hline Nomor Sampel & Konsentrasi $(\mu \mathrm{g} / \mathrm{mL})$ & Luas Area \\
\hline 1 & 99,29 & 2330006 \\
\hline 2 & 99,29 & 2322037 \\
\hline 3 & 99,29 & 2305587 \\
\hline 4 & 99,29 & 2301300 \\
\hline 5 & 99,29 & 2307054 \\
\hline 6 & 99,29 & 2306547 \\
\hline 7 & 99,29 & 2305851 \\
\hline 8 & 99,29 & 2303021 \\
\hline 9 & 99,29 & 2305475 \\
\hline 10 & 99,29 & 2298483 \\
\hline
\end{tabular}

Lihat lampiran 4. Kromatogram Hasil Presisi

Mean

Standard Deviation

Relative Standard Deviation

Limit of Repeatability

Confidence Interval $(\alpha=0.05)$ of $\mathrm{x}$

Kriteria Penerimaan

Kesimpulan :

Dari data tabel diatas menunjukan metoda pemeriksaan penentuan kadar tablet Dietilkarbamazin Sitrat $100 \mathrm{mg}$ hasil pengembangan fase gerak campuaran dapar fosfat dan metanol,memiliki presisi sangat baik karena diperoleh relatif standar deviasi / RSD 0,4231 dimana kriteria penerimaan untuk uji presisi adalah RSD $\leq 2,0 \%$

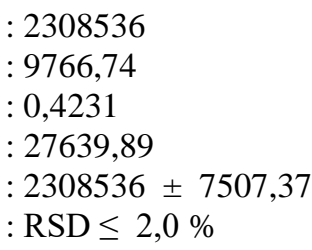

\subsubsection{Akurasi}

Tiga larutan sampel Dietilkarbamazin Sitrat $100 \mathrm{mg}$ tablet dengan tingkatan konsentrasi yang berbeda yaitu $80 \%, 100 \%$ dan $120 \%$ diuji masing-masing 3 kali sesuai dengan metoda pemeriksaan Dietilkarbamazin Sitrat $100 \mathrm{mg}$ tablet. Hasil yang diperoleh adalah sebagai berikut :

\begin{tabular}{|c|c|c|c|c|}
\hline \multicolumn{2}{|c|}{$\begin{array}{c}\text { Konsentrasi } \\
\text { Dietilkarbamazin Sitrat }\end{array}$} & \multirow{2}{*}{$\begin{array}{l}\text { Luas } \\
\text { Area }\end{array}$} & \multirow[t]{2}{*}{ Recovery (\%) } & \multirow{2}{*}{$\begin{array}{c}\text { Kriteria } \\
\text { Penerimaan }\end{array}$} \\
\hline$\mu \mathrm{g} / \mathrm{mL}$ & $\%$ & & & \\
\hline 79,43 & 80 & 1821062 & 99,36 & \\
\hline 79,43 & 80 & 1819064 & 99,25 & \\
\hline 79,43 & 80 & 1815186 & 99,04 & \\
\hline 99,29 & 100 & 2275241 & 99,31 & \\
\hline 99,29 & 100 & 2271053 & 99,13 & \\
\hline 99,29 & 100 & 2272643 & 99,20 & \\
\hline 119,15 & 120 & 2747403 & 99,94 & \\
\hline 119,15 & 120 & 2750551 & 100,05 & \\
\hline 119,15 & 120 & 2748717 & 99,98 & \\
\hline \multicolumn{2}{|c|}{ Mean } & : & 99,48 & $98,0-102,0 \%$ \\
\hline \multicolumn{2}{|c|}{ Standard Deviation } & i & 0,3991 & \\
\hline \multicolumn{2}{|c|}{ Relative Standard Deviatio } & i & 0,4013 & \\
\hline \multicolumn{2}{|c|}{ Limit of Repeatability } & i & 1,1296 & \\
\hline \multicolumn{3}{|c|}{ Confidence Interval $(\alpha=0.05)$ of $\mathrm{x}$} & $99,48 \pm 0,3068$ & \\
\hline
\end{tabular}


Lihat lampiran 5. Kromatogram Hasil Akurasi

Kriteria Penerimaan $\quad: 98,0-102,0 \%$

Kesimpulan :

Dari data tabel diatas menunjukan metoda pemeriksaan penentuan kadar tablet Dietilkarbamazin Sitrat $100 \mathrm{mg}$ hasil pengembangan fase gerak campuaran dapar fosfat dan metanol,memiliki akurasi sangat baik karena diperoleh \% recovery dengan rentang 99,04 - 100,05\% dimana kriteria penerimaan untuk akurasi adalah recovery 98,0-1020\%.

\subsubsection{Linearitas}

Tujuh larutan yang mengandung sampel tablet Dietilkarbamazin Sitrat $100 \mathrm{mg}$ dengan tingkatan konsentrasi yang berbeda diuji masing-masing sesuai dengan metoda pemeriksaan tablet Dietilkarbamazin Sitrat $100 \mathrm{mg}$ yang digunakan. Hasil yang diperoleh adalah sebagai berikut :

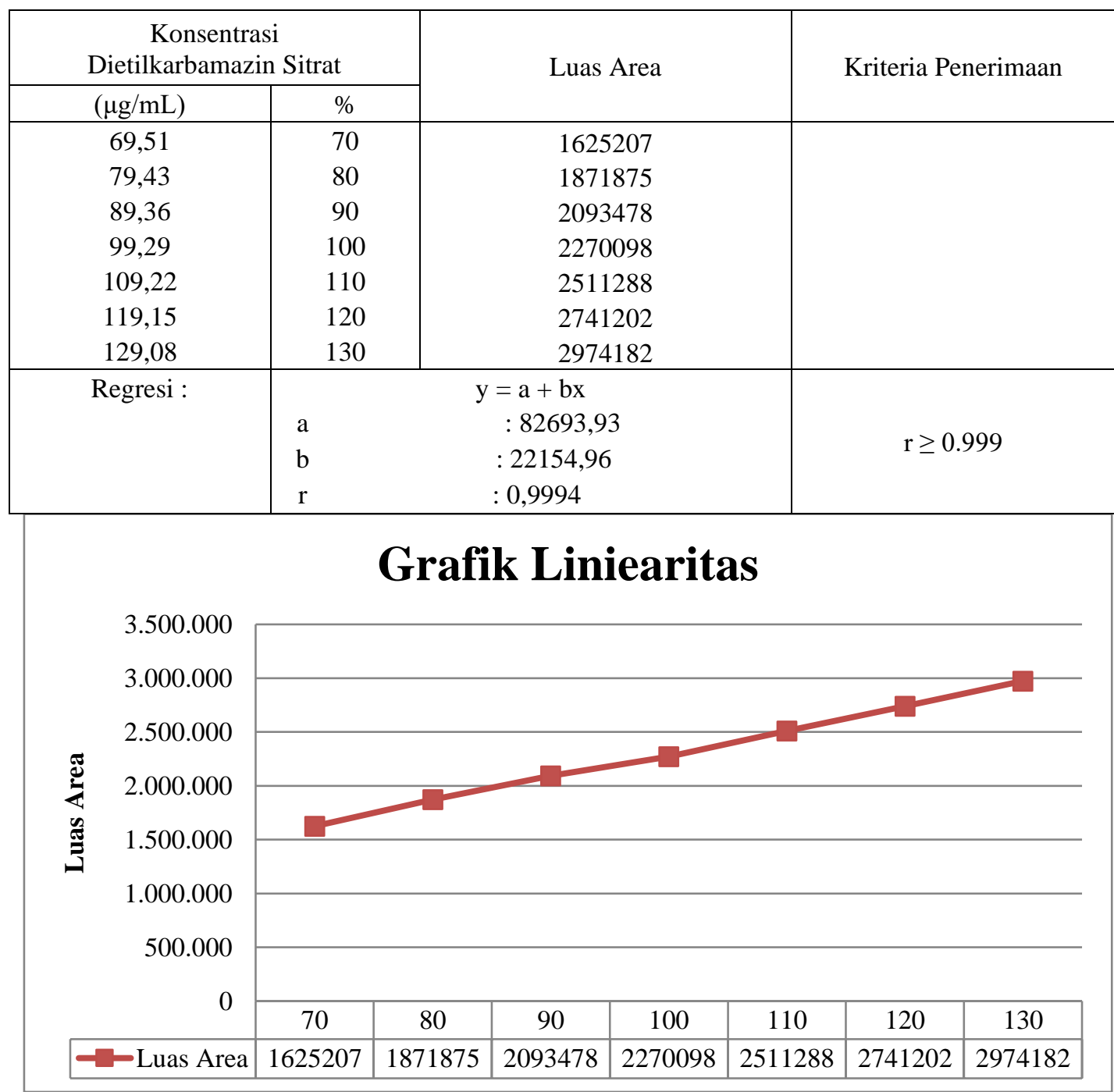

Kesimpulan :

Dari data tabel diatas menunjukan metoda pemeriksaan penentuan kadar tablet Dietilkarbamazin Sitrat $100 \mathrm{mg}$ hasil pengembangan fase gerak campuaran dapar fosfat dan metanol,memiliki linearitas sangat baik karena diperoleh $r=0,9994$ dimana kriteria penerimaan untuk linearitas adalah $r$ $\geq 0,999$. 


\subsubsection{Selektivitas}

a. Prosedur Pelaksanaan

Standar yang ditimbang $=50,2 \mathrm{mg}$

Sampel yang ditimbang $=\mathrm{A}=150,1 \mathrm{mg}$

$\mathrm{B}=150,1 \mathrm{mg} \mathrm{C}=150,1 \mathrm{mg}$

Bobot rata-rata 10 tablet $=302,34 \mathrm{mg}$ b. Hasil Pemeriksaan

Larutan standar, larutan blanko dan larutan sampel diukur dengan menggunakan HPLC pada panjang gelombang $220 \mathrm{~nm}$. Hasil yang diperoleh adalah sebagai berikut :

\begin{tabular}{|c|c|}
\hline \multicolumn{2}{|c}{ Verifikasi } \\
\hline Standar & Luas Area \\
\hline 1 & 2303228 \\
\hline 2 & 2306720 \\
\hline 3 & 2315951 \\
\hline 4 & 2311093 \\
\hline 5 & 2314287 \\
\hline Rata-rata & 2310256 \\
\hline RSD & 0,2283 \\
\hline
\end{tabular}

\begin{tabular}{|c|c|c|c|c|}
\hline Larutan Uji & Luas Area & $\begin{array}{c}\text { Konsentrasi } \\
\text { Dietilkarbamazin Sitrat } \\
(\mu \mathrm{g} / \mathrm{mL})\end{array}$ & $\begin{array}{c}\text { Kadar } \\
(\%)\end{array}$ & $\mathrm{pH}$ \\
\hline Larutan Standar & 2310256 & 100,40 & 99,73 & 4,40 \\
\hline Larutan Blanko & - & - & - & 4,35 \\
\hline Larutan Sampel A & 2301229 & 99,29 & 100,45 & 4,60 \\
\hline Larutan Sampel B & 2296378 & 99,29 & 100,30 & 4,60 \\
\hline Larutan Sampel C & 2302122 & 99,29 & 100,49 & 4,60 \\
\hline
\end{tabular}

Lihat lampiran 7. Kromatogram Hasil Selektivitas

Kriteria Penerimaan : 95,0 \% - 105,0\%

Kesimpulan :

Dari data tabel diatas menunjukan metoda pemeriksaan penentuan kadar tablet Dietilkarbamazin Sitrat $100 \mathrm{mg}$ hasil pengembangan fase gerak campuaran dapar fosfat dan metanol,memiliki selektivitas sangat baik karena diperoleh rentang kadar $=100,30 \%-100,49 \%$ dimana kriteria penerimaan untuk selektivitas adalah 95,0\% $-105,0 \%$.

\subsubsection{Stabilitas Larutan}

Larutan sampel tablet Dietilkarbamazin Sitrat $100 \mathrm{mg}$ disimpan pada suhu ruangan dan dianalisis kembali pada hari ke-2 untuk menentukan stabilitas dari larutan dan sistem yang digunakan. Hasil yang diperoleh adalah sebagai berikut :

\begin{tabular}{|c|c|}
\hline \multicolumn{2}{|c|}{ Verifikasi } \\
\hline Standar & Luas Area \\
\hline 1 & 2292171 \\
\hline 2 & 2290791 \\
\hline 3 & 2287648 \\
\hline 4 & 2311391 \\
\hline 5 & 2306604 \\
\hline Rata-rata & 2297721 \\
\hline RSD & 0,4596 \\
\hline
\end{tabular}




\begin{tabular}{|c|c|c|c|c|}
\hline Larutan Uji & Luas Area & $\begin{array}{c}\text { Konsentrasi } \\
\text { Dietilkarbamazin Sitrat } \\
(\mu \mathrm{g} / \mathrm{mL})\end{array}$ & $\begin{array}{c}\text { Kadar } \\
(\%)\end{array}$ & $\mathrm{pH}$ \\
\hline Larutan Standar & 2310256 & 100,40 & 99,73 & 4,40 \\
\hline Larutan Blanko & - & - & - & 4,35 \\
\hline Larutan Sampel A & 2301229 & 99,29 & 100,45 & 4,60 \\
\hline Larutan Sampel B & 2296378 & 99,29 & 100,30 & 4,60 \\
\hline Larutan Sampel C & 2302122 & 99,29 & 100,49 & 4,60 \\
\hline
\end{tabular}

$\mathrm{T}=24$

\begin{tabular}{|c|c|c|c|c|}
\hline & Luas Area & $\begin{array}{c}\text { Konsentrasi } \\
\text { Dietilkarbamazin Sitrat } \\
(\mu \mathrm{g} / \mathrm{mL})\end{array}$ & $\begin{array}{c}\text { Kadar } \\
(\%)\end{array}$ & $\mathrm{pH}$ \\
\hline Larutan Uji & & & \\
\hline Larutan Standar & 2297721 & 100,40 & 99,73 & 4,38 \\
\hline Larutan Blanko & - & - & - & 4,33 \\
\hline Larutan Sampel A & 2283786 & 99,29 & 100,23 & 4,59 \\
\hline Larutan Sampel B & 2274773 & 99,29 & 99,90 & 4,59 \\
\hline Larutan Sampel C & 2293782 & 99,29 & 100,67 & 4,60 \\
\hline
\end{tabular}

\begin{tabular}{|c|c|c|c|c|}
\hline \multirow{2}{*}{$\begin{array}{c}\text { Hari } \\
\text { Ke - }\end{array}$} & Sampel A & Sampel B & Sampel C & \multirow{2}{*}{$\mathrm{pH}$} \\
\cline { 2 - 4 } 1 & 100,45 & 100,30 & 100,49 & 4,60 \\
\hline 2 & 100,23 & 99,90 & 100,67 & 4,59 \\
\hline
\end{tabular}

Lihat lampiran 8. Kromatogram Hasil Stabilitas Larutan

Kriteria Penerimaan $: \leq 1 \%$

Kesimpulan :

Dari data tabel diatas menunjukan metoda pemeriksaan penentuan kadar tablet Dietilkarbamazin Sitrat $100 \mathrm{mg}$ hasil pengembangan fase gerak campuaran dapar fosfat dan metanol,memiliki stabilitas larutan sangat baik karena diperoleh rentang selisih kadar hari pertama dan hari kedua adalah = 0,18 - 0,40 dimana kriteria penerimaan untuk stabilitas larutan adalah selisih kadar adalah $\leq 1 \%$.

\subsubsection{Rentang}

Hasil analisis pada penentuan akurasi dan linearitas, didapatkan hasil sebagai berikut :

\section{Akurasi}

Rentang antara

: $80 \%-120 \%$

Hasil Pemeriksaa

$98,0 \%-102,0 \%$ )

\section{Linearitas}

$\begin{array}{ll}\text { Rentang antara } & : 70 \%-130 \% \\ \text { Hasil Pemeriksaan } & : \text { r } 0,9994 \text { ( syarat }\end{array}$

$: r \geq 0,999$ )

Kesimpulan :

Dari data tabel diatas menunjukan metoda pemeriksaan penentuan kadar tablet Dietilkarbamazin Sitrat $100 \mathrm{mg}$, hasil pengembangan fase gerak campuaran dapar fosfat dan metanol, valid karena diperoleh akurasi pada rentang $80 \%-120 \%$ yaitu $99,48 \%$ dengan syarat $98,0 \%-102,0 \%$ serta diperoleh hasil linearitas pada rentang konsetrasi $70 \%$ - $130 \%$ yaitu r $\quad 0,9994$ dengan syarat $r \geq 0,999$.

\subsubsection{Uji Kesesuaian Sistem}

Injekkan larutan standar sebanyak 5 kali, lalu hitung uji kesesuaian sistem dari 5 kromatogram standar. Hasil yang didapat sebagai berikut: 


\begin{tabular}{|c|c|c|c|c|}
\hline Zat Akif & $\begin{array}{c}\text { Luas } \\
\text { Area }\end{array}$ & $\begin{array}{c}\text { Waktu Retensi } \\
(\mathrm{t}) \text { menit }\end{array}$ & $\begin{array}{c}\text { Theoritical Plate } \\
(\mathrm{n})\end{array}$ & $\begin{array}{c}\text { Tailing Faktor } \\
(\mathrm{T})\end{array}$ \\
\hline Dietilkarbamazin Sitrat & 2303228 & 5,70 & 2681 & 2,225 \\
\hline Dietilkarbamazin Sitrat & 2306720 & 5,70 & 2707 & 2,231 \\
\hline Dietilkarbamazin Sitrat & 2315951 & 5,70 & 2698 & 2,232 \\
\hline Dietilkarbamazin Sitrat & 2311093 & 5,70 & 2710 & 2,227 \\
\hline Dietilkarbamazin Sitrat & 2314287 & 5,70 & 2727 & 2,237 \\
\hline RSD & 0,2283 & 0,083 & 0,6234 & 0,2093 \\
\hline
\end{tabular}

Lihat lampiran 9. Kromatogram Hasil Uji Kesesuaian Sistem

Kriteria Penerimaan : RSD $\leq 2.0 \%$

Kesimpulan :

Dari data tabel diatas menunjukan metoda pemeriksaan penentuan kadar tablet Dietilkarbamazin Sitrat $100 \mathrm{mg}$, hasil pengembangan fase gerak campuaran dapar fosfat dan metanol, memiliki kesesuaian sistem sangat baik karena diperoleh RSD kesesuaian sistem yaitu $0,2283 \%$ dengan syarat $\mathrm{RSD} \leq 2,0 \%$.

\subsubsection{Robustness}

a. Prosedur Pelaksanaan

Standar yang ditimbang $=50,2 \mathrm{mg}$

Sampel yang ditimbang $=\mathrm{A}=150,1 \mathrm{mg}$ $\mathrm{B}=150,1 \mathrm{mg} \mathrm{C}=150,1 \mathrm{mg}$

Bobot rata-rata 10 tablet $=302,34 \mathrm{mg}$

b. Hasil Pemeriksaan

Larutan standar, larutan blanko dan larutan sampel diukur menggunakan HPLC pada panjang gelombang $220 \mathrm{~nm}$ menggunakan kolom yang berbeda dari yang digunakan dalam pemeriksaan sebelumnya yaitu kolom L1; $5 \mu \mathrm{m}$; ( 4,6 x 250 ) mm; Inertsil ODS 3, sebelumnya menggunakan kolom L1; $5 \mu \mathrm{m}$; ( 4,6 x 150 ) mm; Inertsil ODS 3 Hasil yang diperoleh adalah sebagai berikut :

\begin{tabular}{|c|c|}
\hline \multicolumn{2}{|c|}{ Verifikasi } \\
\hline Standar & Luas Area \\
\hline 1 & 2329581 \\
\hline 2 & 2335316 \\
\hline 3 & 233209 \\
\hline 4 & 2335015 \\
\hline 5 & 2337521 \\
\hline Rata-rata & 2334128 \\
\hline RSD & 0,1271 \\
\hline
\end{tabular}

\begin{tabular}{|c|c|c|c|c|}
\hline Larutan Uji & Luas Area & $\begin{array}{c}\text { Konsentrasi } \\
\text { Dietilkarbamazin Sitrat } \\
(\mu \mathrm{g} / \mathrm{mL})\end{array}$ & $\begin{array}{c}\text { Kadar } \\
(\%)\end{array}$ & $\mathrm{pH}$ \\
\hline Larutan Standar & 2334128 & 100,80 & 99,73 & 4,43 \\
\hline Larutan Blanko & - & - & - & 4,37 \\
\hline Larutan Sampel A & 2252696 & 99,29 & 97,71 & 4,55 \\
\hline Larutan Sampel B & 2248122 & 99,29 & 97,51 & 4,57 \\
\hline Larutan Sampel C & 2244428 & 99,29 & 97,35 & 4,55 \\
\hline
\end{tabular}

Lihat lampiran 10. Kromatogram Hasil Robustness

\section{Simpulan dan Saran}

\subsection{Simpulan}

1. Hasil optimasi fase gerak campuran larutan dapar fosfat dan metanol pada metoda analisis penentuan kadar tablet
Dietilkarbamazin Sitrat $100 \mathrm{mg}$ adalah fase gerak campuran larutan dapar fosfat dan metanol dengan perbandingan ( 80 : 20 ) 
2. Metoda analisis penentuan kadar tablet Dietilkarbamazin Sitrat $100 \mathrm{mg}$ hasil pengembang komposisi fase gerak dinyatakan valid dan dapat digunakan untuk menganalisa kadar sampel tablet Dietilkarbamazin Sitrat $100 \mathrm{mg}$.

3. Hasil validasi metoda analisa tablet Dietilkarbamazin Sitrat $100 \mathrm{mg}$ adalah RSD Presisi 0,4231 \%, \% Recovery Akurasi 99,48 \%, r Linearitas 0,9994, RSD Kesesuaian sistem 0,2283 \%, Selektivitas dengan rentang kadar 100,30 $\%-100,49 \%$.

\subsection{Saran}

Untuk mempercepat waktu anlisa Pada analisa sampel menggunakan metoda kromatografi cair kenerja tinggi hal - hal yang perlu di perhatikan adalah komposisi fase gerak, jenis kolom dan laju alir fase gerak .

Pada penelitian ini telah dilakukan optimasi komposisi fase gerak dan memperoleh hasil waktu analisa penentuan kadar tablet dietilkarbamazin sitrat $100 \mathrm{mg}$ lebih cepat dari metoda sebelumnya.

Daftar Pustaka

Departemen Kesehatan RI. 2009. Suplemen II Farmakope Indonesia Edisi IV. Jakarta : Departemen Kesehatan RI. Halaman 1853-1856.

Departemen Kesehatan RI. 2014.

Farmakope Indonesia Edisi V. Jakarta : Departemen Kesehatan RI. Halaman 312 313.

Ermer $\mathrm{J}$ and Miller JH McB., Method validation in Pharmaceutical Analysis., Wiley-VCH, 2005

Harmit., Desember 2004., Petujuk pelaksanaan validasi metode dan
Penulis menyarankan untuk di lakukan penelitian lanjutan dengan mengoptimasi jenis kolom dan laju alir fase gerak sehingga diperoleh waktu analisa yang cepat dan optimal.

\section{Daftar Lampiran}

1. Kromatogram Perbadingan Fase Gerak 60 : 40

2. Kromatogram Perbandingan Fase Gerak $70: 30$

3. Kromatogram Perbandingan Fase Gerak $80: 20$

4. Kromatogram Hasil Presisi

5. Kromatogram Hasil Akurasi

6. Kromatogram Hasil Liniearitas

7. Kromatogram Hasil Selektivitas

8. Kromatogram Hasil Stabilitas Larutan

9. Kromatogram Hasil Uji Kesesuaian Sistem

10. Kromatogram Hasil Robustness

cara perhitungannya., Departemen Farmasi FMIPA-UI., Jurnal Majalah Ilmu Kefarmasian, volume I. No. 3.

Masrizal., September 2012- Maret 2013., Penyakit Filariasis., Jurnal Kesehatan Masyarakat. Volume 7. No. 1.

Usman , H., Dan R. Purnomo Setiady Akbar., 2000., Pengantar Statistika. Jakarta., Bumi Aksara

United State Pharmacopeial Convetion., 2013., United State Pharmacopeia 36 NF 31. Volume II. Baltimore : United Book Press, Inc. halaman 3234 - 3235 